\title{
Noninvasive screening for genital chlamydial infections in asymptomatic men: Strategies and costs using a urine PCR assay
}

Rosanna W Peeling $\mathrm{PhD}^{1}$, Baldwin Toye $\mathrm{MD}^{2,4}$, Peter Jessamine $\mathrm{MD}^{3,4}$, Ian Gemmill $\mathrm{MD}^{5}$

\begin{abstract}
RW Peeling, B Toye, P Jessamine, I Gemmill. Noninvasive screening for genital chlamydial infections in asymptomatic men: Strategies and costs using a urine PCR assay. Can J Infect Dis 1998;9(5):281-286.

OBJECTIVE: To evaluate cost saving strategies to screen for genital chlamydial infection in men using polymerase chain reaction (PCR) technology.

METHODS: Men with no urethral symptoms presenting to a sexually transmitted disease (STD) clinic were recruited. Study participants underwent a questionnaire interview. Urethral swabs were taken to perform a smear for polymorphonuclear leucocytes (PMN) and for the detection of Chlamydia trachomatis by culture and PCR. First-catch urine was collected for a leukocyte esterase test (LET) and PCR.

RESULTS: C trachomatis infection was detected in 36 of 463 (7.8\%) men. LET and PMN were positive in 10 (28\%) and 12 (33\%) infected men, respectively. Risk factors for chlamydial infection were younger than age 25 years, LET-positive, PMN-positive and STD contact $(\mathrm{P}<0.001)$. The direct cost of genital chlamydial infection in men in Canada has been previously estimated at $\$ 381 /$ case. Based on a sensitivity of $90 \%$ for urine PCR, the estimated direct cost of testing all participants to detect 32 cases was $\$ 453 /$ case. Using risk factors recommended in the Canadian STD Guidelines (age younger than 25 years, new partner, STD contact or unprotected sex), the same number of cases would have been detected by testing only 384 men at $\$ 376 /$ case. Using age younger than 25 years or STD contact as the screening criterion, $78 \%$ of those infected would have been detected at $\$ 259 /$ case, and no new cases would have been detected by adding LET-positive or PMN-positive as risk factors.

CONCLUSION: Targeted screening for chlamydial infection using urine PCR assay and risk factors recommended in the Canadian guidelines could substantially reduce the cost of screening at a STD clinic setting. LET and PMN smear did not appear to be useful indicators of chlamydial infection in this population.
\end{abstract}

Key Words: Chlamydia trachomatis, Costs, Polymerase chain reaction, Screening

Pour le résumé, voir page 282

This work was presented in part at the 11th International Society for Sexually Transmitted Disease Research Meeting in New Orleans, August 27-30, 1995, abstract \#331 and at the 35th Interscience Conference on Antimicrobial Agents and Chemotherapy in San Francisco, September 17-20, 1995, abstract \#K78

${ }^{1}$ Laboratory Centre for Disease Control, Winnipeg, Manitoba; ${ }^{2}$ Ottawa General Hospital; ${ }^{3}$ Ottawa Civic Hospital; ${ }^{4}$ University of Ottawa; ${ }^{5}$ Ottawa-Carleton Health Department, Ottawa, Ontario

Correspondence and reprints: Dr Rosanna Peeling, Laboratory Centre for Disease Control, 1015 Arlington Street, Winnipeg, Manitoba R3E 3R2. Telephone 204-789-2144, fax 204-789-2140, e-mail rosanna_peeling@hc-SC.gC.ca

Received for publication October 9, 1997. Accepted December 13, 1997 


\title{
Dépistage non sanglant des infections génitales à Chlamydia chez les hommes asymptomatiques : stratégies et coûts de l'utilisation de la technique d'amplification en chaîne par la polymérase pour analyser l'urine
}

\begin{abstract}
OBJECTIF : Évaluer des approches moins coûteuses pour dépister l'infection génitale à Chlamydia chez les hommes en faisant appel à la technique d'amplification en chaîne par la polymérase (PCR).

MÉTHODES : Des hommes sans symptômes urétraux se présentant à une clinique de maladies transmises sexuellement (MTS) ont été recrutés. Les participants à l'étude ont subi une entrevue sous forme de questionnaire. On a procédé à un écouvillonnage des écoulements urétraux pour préparer un frottis afin de déceler des leucocytes polynucléaires (LP) et dépister Chlamydia trachomatis par culture et par PCR. Le premier jet d'urine a été recueilli pour un dosage des estérases leucocytaires (DEL) et pour la PCR.

RÉSULTATS : Une infection à Chlamydia trachomatis a été décelée chez 36 des 463 (7,8\%) hommes. Les résultats du DEL et de la recherche des LP étaient respectivement positifs chez $10(28 \%)$ et 12 (33\%) des hommes infectés. Les facteurs de risque pour une infection à Chlamydia étaient le fait d'être âgé de moins de 25 ans, d'avoir un DEL positif et un résultat positif pour les LP, et d'avoir eu un contact avec une personne porteuse d'une MTS (P,001). Au Canada, le coût direct d'une infection génitale à Chlamydia chez les hommes a déjà été estimé à 381 dollars par cas. En se basant sur une sensibilité de $90 \%$ de l'analyse d'urine par PCR, le coût direct estimé du dépistage de tous les participants pour déceler 32 cas était de 453 dollars par cas. En utilisant les facteurs de risque recommandés dans les Lignes directrices canadiennes sur la prise en charge des maladies transmises sexuellement (sujet de moins de 25 ans, nouveau partenaire, contact avec un sujet porteur d'une MTS ou relations sexuelles non protégées) le même nombre de cas aurait été décelé en testant seulement 384 hommes à 376 dollars par cas. En utilisant comme critères de dépistage le fait d'être âgé de moins de 25 ans ou d'avoir été exposé à une MTS, 78 \% des sujets infectés auraient été décelés à 259 dollars par cas, et aucun nouveau cas n’aurait été décelé en ajoutant comme facteurs de risque la positivité au DEL et la présence de LP sur le frottis.

CONCLUSION : Un dépistage ciblé pour l'infection à Chlamydia faisant appel à une analyse d'urine par PCR et se basant sur les recommandations des Lignes directrices canadiennes sur les facteurs de risque pourrait réduire de façon substantielle le coût du dépistage dans une clinique de dépistage des MTS. Le DEL et la recherche de LP par frottis ne semblent pas être des indicateurs utiles d'une infection à Chlamydia dans cette population.
\end{abstract}

$\mathrm{G}$ enital chlamydial infections are the most frequently reported communicable disease in Canada (1). Most chlamydial infections are mild or asymptomatic, but silent infections in women may lead to long term reproductive sequelae, such as pelvic inflammatory disease, ectopic pregnancy and infertility. Infected individuals are at increased risk of acquisition of human immunodeficiency virus (HIV) (2). In the United States, it is estimated that four million new cases of genital chlamydial infection occur per year, and 50,000 women become infertile each year as a result $(3,4)$. In Canada, approximately 40,000 new cases occur every year, with $70 \%$ of the reported infections occurring in the 15 to 24 year age group $(5,6)$. The total burden-of-illness cost for genital chlamydial infections in Canada was estimated to be in excess of $\$ 89$ million dollars in 1990 (7).

Because $50 \%$ to $70 \%$ of genital chlamydial infections can be asymptomatic, widespread screening for chlamydial infections in women was initiated in the late 1980s. Efforts at screening for infections in men, however, have not been as successful. Men do not access the health care system as often as women and are often reluctant to undergo urethral swabbing in the absence of any urethral symptoms. As a result, first-catch urine (FCU) specimens were introduced as a noninvasive alternative for diagnosing asymptomatic infections in men. Unfortunately, testing FCU using enzyme immuoassays (EIAs) showed a sensitivity of only $44 \%$ to $85 \%$ compared with urethral swab culture (8). This suboptimal performance has been attributed to the low bacterial burden in asymptomatic men $(9,10)$.

The advent of nucleic acid amplification technology, such as polymerase chain reaction (PCR), ligase chain reaction (LCR) and transcription mediated amplification, has brought dramatic improvements in test performance over culture and other nonculture tests because of lower detection thresholds. Recent studies have shown that the assays can also be used on FCU from both men and women (11-22). However, these nucleic acid-based assays are technically more demanding and more costly than nonculture tests such as EIA, which are currently used in most laboratories. One strategy that could reduce the cost of testing is to prescreen with simple, rapid and inexpensive tests that are indicators of urethral inflammation, such as the leucocyte esterase test (LET) or the presence of four polymorphonuclear leukcocytes (PMNs) or more per high power field in a Gram-stained smear. In earlier studies, LET showed promise as an inexpensive and rapid on-site screening tool (8). However, recent evaluations of LET showed equivocal results (23-30). Another means of reducing cost of screening programs is to use risk assessment. The Canadian STD Guidelines (31) recommend screening if an individual fits any one of the following categories: younger than 25 years of age, injection drug user or substance abuser, street youth, a history of sexually transmitted disease (STD) in the past year, a new partner in the past two months, two or more partners in the past year, the use of noncondom contraception, or unprotected sex with any of the above.

The objective of this study was to determine strategies to reduce the cost of PCR screening for asymptomatic Chlamydia trachomatis infection in men using combinations of rapid screening tests and risk assessment.

\section{PATIENTS AND METHODS}

Study subjects: Consecutive men with no urethral symptoms presenting to the Ottawa-Carleton Sexual Health Centre, Ottawa, Ontario were asked to participate in the study as previously described (12). Of the 472 men who gave informed consent, information from the standardized questionnaire in- 
TABLE 1

Specific costs estimated for screening of men attending a sexually transmitted disease clinic

Test to test kit and supplies $=\$ 10.51$

Technologist time $(\$ 22.40 / \mathrm{h} \times 10$ mins $)=\$ 3.73$

Professional billing $=\$ 17.07$

Total estimated direct cost per test $=\$ 31.31$

Estimated cost/case $=[\$ 31.31 \times$ number of men tested $] /$ number of cases detected

terview, which included a sexual history and inquiry regarding condom usage, was obtained from 463 men.

Laboratory tests: Two urethral swab specimens were obtained on Dacron swabs from all study participants who had not voided in the previous $2 \mathrm{~h}$. The first swab specimen was placed immediately into chlamydia transport medium and stored at $4^{\circ} \mathrm{C}$. Samples were processed for $C$ trachomatis culture using Hela 229 cells and for PCR (Amplicor $C$ trachomatis assay, Roche Diagnostics Systems, New Jersey) (12). The second specimen was obtained for a Gram-stained smear for PMNs, and for Neisseria gonorrhoeae culture as part of the clinic protocol. After the urethral swabs were taken, FCU specimens $(20 \mathrm{~mL})$ were collected from a subset of men $(n=379)$ for the LET (Boehringer Mannheim) and for PCR. Discrepant results between urethral culture and urine or urethral swab PCR were confirmed by another PCR reaction using primers for the chlamydial major outer membrane protein (12). A $1+$ score for the LET and a count of four PMNs per high power field were considered positive results. Study participants were considered infected with $C$ trachomatis if they were either culture or confirmed PCR positive (12).

Cost estimations: The direct cost of chlamydial infection in men in Canada, which included laboratory testing and professional billing, was estimated to be $\$ 4,510,555$ in 1990 (7). Because 11,709 cases of genital chlamydial infection in men were reported in Canada in 1990, this is equivalent to a direct cost of $\$ 381$ per case. This estimate has remained fairly constant, hence $\$ 381$ per case was used as the comparison for screening costs.

In this study, the estimated laboratory costs included the cost of PCR test kits and supplies, which may vary from laboratory to laboratory depending on the volume of testing. The cost of supplies included urine containers, aerosol-free plugged pipette tips, tubes and gloves. Technologist's time was estimated at a rate of $\$ 20.00$ an hour plus $12 \%$ benefits. The cost estimate for professional billing was based on Goeree and Gully's calculation (7) for a minor assessment by a physician because the patient was not symptomatic and was being screened when he accessed the health care system for another complaint. Specific costs are presented in Table 1.

The various screening strategies were examined using a combination of risk factors and rapid screening tests, and the authors determined strategies whose direct cost did not exceed the estimated direct cost spent per case of chlamydial infection in men in Canada.

Data analyses: $\chi^{2}$ analyses with Yates correction or the Fisher's exact test were used to compare differences in proportions. Student's $t$ test was used for paired comparisons.

\section{RESULTS}

The prevalence of $C$ trachomatis infection in this population was $7.8 \%$ (36 of 463) (12). The demographics and risk factors of infected and noninfected individuals are shown in Table 2 . The mean age of the participants was $28.7 \pm 8.9$ years (range 15 to 68 ), whereas the mean age of infected men was $25 \pm 6$ years (range 18 to 32 ). There was a significant differ-

TABLE 2

Risk factors for asymptomatic chlamydial infection in men attending a sexually transmitted disease (STD) clinic $(n=463$, prevalence of infection $=7.8 \%$ )

\begin{tabular}{|c|c|c|c|c|}
\hline Risk factors & Ct-positive $(n=36)$ & Ct-negative $(n=427)$ & $\mathbf{P}$ & OR $(95 \% \mathrm{CI})$ \\
\hline Age $($ mean $\pm S D)$ & $25 \pm 6$ & $29 \pm 9$ & $<0.001$ & \\
\hline Median, range & $23,18-32$ & $27,15-68$ & & \\
\hline Number age 25 years or less & $27(75 \%)$ & $177(42 \%)$ & 0.009 & $3.6(1.3,10.9)$ \\
\hline Number age 30 years or less & $31(86 \%)$ & $269(63 \%)$ & $<0.001$ & $4.2(1.8,10.0)$ \\
\hline LE-positive & $10(28 \%)$ & $25(6 \%)$ & $<0.001$ & $6.2(2.5,15.3)$ \\
\hline PMN smear-positive & $12(33 \%)$ & $14(3 \%)$ & $<0.001$ & $14.8(5.7,38.6)$ \\
\hline Gay or bisexual & $0 / 0$ & $32 / 8$ & $0.17 / 1.0$ & - \\
\hline STD contact & $20(56 \%)$ & $49(12 \%)$ & $<0.001$ & $9.6(4.4,21.1)$ \\
\hline New partner & $11(31 \%)$ & $163(38 \%)$ & 0.47 & \\
\hline History of STD & $9(25 \%)$ & $106(25 \%)$ & 0.86 & \\
\hline Number of partners in past two months (mean \pm SD) & $1.3 \pm 1.1$ & $1.3 \pm 1.04$ & 0.08 & \\
\hline Median/range & $1 / 0-6$ & $1 / 0-12$ & & \\
\hline Number of partners in past 12 months (mean \pm SD) & $3.9 \pm 5.2$ & $2.8 \pm 2.8$ & 0.23 & \\
\hline Median/range & $2 / 1-30$ & $2 / 0-40$ & & \\
\hline \multicolumn{5}{|l|}{ Condom use } \\
\hline Never & $19(53 \%)$ & $157(37 \%)$ & & \\
\hline Occasionally & $16(44 \%)$ & $186(44 \%)$ & & \\
\hline Always & $1(3 \%)$ & 84 (20\%) & 0.09 & \\
\hline
\end{tabular}

Ct Chlamydia trachomatis; LE Leukocyte esterase; PMN Polymorphonuclear leukocyte 
TABLE 3

Cost of different screening strategies for men aged younger than 25 years attending a sexually transmitted disease (STD) clinic

\begin{tabular}{|c|c|c|c|c|}
\hline Screening criteria & $\begin{array}{l}\text { Number of men who } \\
\text { met screening criteria }\end{array}$ & $\begin{array}{c}\text { Number of cases detected } \\
\text { at } 100 \% \text { sensitivity }\end{array}$ & $\begin{array}{l}\text { Number of cases detected at } \\
90 \% \text { sensitivity }\end{array}$ & Cost per case* $(\$)$ \\
\hline Age younger than 25 years or LE-positive & $226(49 \%)$ & $28 / 36(78 \%)$ & $25 / 36(69 \%)$ & 283 \\
\hline $\begin{array}{l}\text { Age younger than } 25 \text { years or smear- } \\
\text { positive }\end{array}$ & $215(46 \%)$ & $29 / 36(81 \%)$ & $26 / 36(72 \%)$ & 259 \\
\hline $\begin{array}{l}\text { Age younger than } 25 \text { years or } \\
\text { LE-positive/smear-positive }\end{array}$ & $234(51 \%)$ & $30 / 36(83 \%)$ & $27 / 36(75 \%)$ & 271 \\
\hline $\begin{array}{l}\text { Age younger than } 25 \text { years or STD } \\
\text { contact }\end{array}$ & $232(50 \%)$ & $31 / 36(86 \%)$ & $28 / 36(78 \%)$ & 259 \\
\hline $\begin{array}{l}\text { Age younger than } 25 \text { years or } \\
\text { STD contact or LE-positive }\end{array}$ & $250(54 \%)$ & $31 / 36(86 \%)$ & $28 / 36(78 \%)$ & 280 \\
\hline $\begin{array}{l}\text { Age younger than } 25 \text { years or new part- } \\
\text { ner or STD contact }\end{array}$ & $320(69 \%)$ & $34 / 36(94 \%)$ & $31 / 36(86 \%)$ & 323 \\
\hline $\begin{array}{l}\text { Age younger than } 25 \text { years or new } \\
\text { partner or STD contact or LE-positive }\end{array}$ & $331(71 \%)$ & $34 / 36(94 \%)$ & $31 / 36(86 \%)$ & 334 \\
\hline $\begin{array}{l}\text { Age younger than } 25 \text { years or new part- } \\
\text { ner or STD contact or never uses con- } \\
\text { dom }\end{array}$ & $384(83 \%)$ & $35 / 36(97 \%)$ & $32 / 36(89 \%)$ & 376 \\
\hline
\end{tabular}

${ }^{*}$ Costs based on a screening assay with 90\% sensitivity; cost/case $=\$ 31.31 \times$ number of men tested/number of cases detected at $90 \%$ sensitivity. LE Leukocyte esterase

TABLE 4

Cost of different screening strategies for men younger than age 30 years attending a sexually transmitted disease (STD) clinic

\begin{tabular}{|c|c|c|c|c|}
\hline Screening criteria & $\begin{array}{l}\text { Number of men who } \\
\text { met screening criteria }\end{array}$ & $\begin{array}{l}\text { Number of cases detected } \\
\text { at } 100 \% \text { sensitivity }\end{array}$ & $\begin{array}{c}\text { Number of cases detected at } \\
90 \% \text { sensitivity }\end{array}$ & $\begin{array}{l}\text { Cost per } \\
\text { case* }^{*}(\$)\end{array}$ \\
\hline Age 30 years or younger or LE-positive & $312(67 \%)$ & $31 / 36(86 \%)$ & $28 / 36(78 \%)$ & 349 \\
\hline Age 30 years or younger or STD contact & $313(68 \%)$ & $32 / 36(89 \%)$ & $29 / 36(81 \%)$ & 338 \\
\hline $\begin{array}{l}\text { Age } 30 \text { years or younger or STD contact } \\
\text { or LE-positive }\end{array}$ & $323(70 \%)$ & $32 / 36(89 \%)$ & $29 / 36(81 \%)$ & 349 \\
\hline $\begin{array}{l}\text { Age } 30 \text { years or younger or new partner or } \\
\text { STD contact or never uses condoms }\end{array}$ & $414(89 \%)$ & $36 / 36(100 \%)$ & $32 / 36(89 \%)$ & 405 \\
\hline
\end{tabular}

${ }^{*}$ Costs based on a screening assay with 90\% sensitivity; cost/case $=\$ 31.31 \times$ number of men tested/ number of cases detected at $90 \%$ sensitivity. LE Leukocyte esterase

TABLE 5

Cost of different screening strategies for men younger than age 35 years attending a sexually transmitted disease (STD) clinic

\begin{tabular}{|c|c|c|c|c|}
\hline Screening criteria & $\begin{array}{l}\text { Number of men who } \\
\text { met screening criteria }\end{array}$ & $\begin{array}{c}\text { Number of cases detected } \\
\text { at } 100 \% \text { sensitivity }\end{array}$ & $\begin{array}{c}\text { Number of cases detected at } \\
90 \% \text { sensitivity }\end{array}$ & $\begin{array}{c}\text { Cost per case* } \\
(\$)\end{array}$ \\
\hline Age 35 years or younger or LE-positive & $383(83 \%)$ & $33 / 36(92 \%)$ & $30 / 36(83 \%)$ & 400 \\
\hline Age 35 years or younger or STD contact & $379(82 \%)$ & $33 / 36(92 \%)$ & $30 / 36(83 \%)$ & 396 \\
\hline $\begin{array}{l}\text { Age } 35 \text { years or younger or STD contact } \\
\text { or LE-positive }\end{array}$ & $384(83 \%)$ & $33 / 36(92 \%)$ & $30 / 36(83 \%)$ & 401 \\
\hline $\begin{array}{l}\text { Age } 35 \text { years or younger or new partner } \\
\text { or STD contact or never uses condoms }\end{array}$ & $433(94 \%)$ & $36 / 36(100 \%)$ & $32 / 36(89 \%)$ & 424 \\
\hline
\end{tabular}

${ }^{*}$ Costs based on a screening assay with 90\% sensitivity; cost/case $=\$ 31.31 \times$ number of men tested/ number of cases detected at 90\% sensitivity. LE Leukocyte esterase

ence in mean age between those who were infected with $C$ trachomatis and those who were not $(\mathrm{P}<0.0001)$. LET and PMN were positive in $10(28 \%)$ and $12(33 \%)$ of infected men, respectively. Men infected with $C$ trachomatis were younger, more likely to be LET- and PMN-positive, and were a sexual contact of a person with an STD compared with those who were not infected $(\mathrm{P}<0.001)$. A history of STD, a new partner in the past two or 12 months and no condom use were not significantly different in the infected and noninfected groups. In men older than 25 years of age, risk factors for chlamydial infection were
PMN-positive and STD contact $(\mathrm{P}=0.05$ and $\mathrm{P}=0.01$, respectively). The estimated costs of screening using different prescreening tests (LET or PMN) and risk factors as screening criteria are shown in Tables 3 to 5 . Based on a previously determined sensitivity of $90 \%$ for urine PCR (12) and a prevalence of infection of $7.8 \%$, the direct cost of testing all participants to detect 32 cases was $\$ 453 /$ case. Using risk factors recommended in the Canadian guidelines (age younger than 25 years, new partner, STD contact or unprotected sex), and the same test sensitivity, the same number of cases would 
have been detected by testing only 384 men at a cost of $\$ 376 /$ case. Using age younger than 25 years or STD contact as screening criteria, 28 (78\%) of those infected would have been detected by screening 232 men (69\%) at a cost of $\$ 259 /$ case. In this population, raising the age threshold for screening to include those 35 years of age or younger substantially increased the cost of testing, with the result that the cost of screening exceeded the cost/case in Canada estimated by Goeree and Gully (7).

\section{DISCUSSION}

Asymptomatic chlamydial infection in men represents an important reservoir of disease transmission. Screening for genital chlamydial infections using nucleic acid amplification technology on noninvasive specimens such as urine will likely improve test sensitivity as well as compliance for screening. Universal screening in STD clinic settings has been recommended in some studies $(32,33)$. We have shown in this study that targeted screening using risk assessment recommended in the Canadian STD Guidelines would detect the same number of cases as would universal screening, but at substantially reduced costs.

Age younger than 25 years remains the single most useful criterion for screening in this STD clinic setting. In this study population, $75 \%$ of the infected men were younger than 25 years of age and $86 \%$ were 30 years of age or younger. If age younger than 25 years was used as a risk factor for screening, $67 \%$ of those infected would have been detected. Sexual contact with a partner with an STD was also a useful indicator for screening, which is often used routinely in this population. Based on a screening assay sensitivity of $90 \%$ and risk criteria of age younger than 25 years and STD contact, only $50 \%$ of the study participants would need to be tested to detect $78 \%$ of the cases, at $57 \%(\$ 259 / \$ 453)$ of the cost of universal screening (Table 3). Current Canadian STD Guidelines recommend other risk factors for screening such as a new partner in the past two months, two or more partners in the past year or a history of STD. Although these risk factors were not found to be useful predictors of chlamydial infection in this study population, the use of these risk criteria for screening is at the discretion of health care providers who should be knowledgeable about the population that they serve.

Although the LET and the PMN smears were significantly more often positive in infected men than in uninfected men, these tests were not sufficiently sensitive to be useful indicators to reduce the cost of screening in this population. As shown in Tables 3 to 5, if age and STD contact were used as screening criteria, the use of LET or PMN would not have detected any additional cases. Genç et al (34) found that a combination of LET and EIA screening was cost effective for detecting chlamydial infection in adolescent males. In recent years, the LET has shown variable performance as a predictor of asymptomatic chlamydial infection in men with sensitivities ranging from $57 \%$ to $100 \%$ compared with culture or LCR $(8,23-30)$. The poor sensitivity of LET obtained in this study is consistent with the findings of Chow et al (23) who showed that LET sensitivity was $54 \%$ compared with cervical culture and $53 \%$ compared with urine LCR in a study of 4053 women attending STD and family planning clinics (23). It is possible that the improved sensitivity of LCR or PCR assays has superseded the usefulness of LET because molecular tests can identify infection in patients whose level of urethral inflammation may be below the detection limit of LET.

The usefulnesss of PMN count in Gram-stained urethral smears also appears to vary $(35,36)$. The presence of PMN in a urethral smear is an indicator of urethral inflammation. The degree of inflammation may be low in asymptomatic men, and it is, thus, not surprising that we did not find PMN count to be a useful predictor of genital chlamydial infection in our study population. In a study of chlamydial infection in 219 men using culture and EIA, Janier et al (35) found that the presence of PMN on urethral swab or FCU as a predictor of genital chlamydial infection had a sensitivity of $43 \%$ in patients with no urethral discharge compared with $90 \%$ in those with discharge.

The best estimate of the total burden-of-illness cost of genital chlamydial infections and associated sequelae in Canada for both men and women in 1990 was $\$ 89,090,276$ (7). The majority (74\%) of the cost for male infection was for diagnostic and screening tests at a direct cost of $\$ 381$ per case. In contrast, $72 \%$ of the estimated cost per case for women was for the diagnosis and care of reproductive sequelae, such as pelvic inflammatory disease, ectopic pregnancy and tubal infertility. This resulted in a substantially higher cost per case of $\$ 2,224.83$ for women, not to mention the human costs associated with adverse reproductive sequelae. Based on a screening assay sensitivity of $90 \%$ and a risk criterion of age younger than age 25 years or STD contact, we have shown that only $50 \%$ of the study participants would need to be tested to detect $78 \%$ of the cases, at $57 \%(\$ 259 / \$ 453 \times 100)$ of the cost of universal screening. This cost is only $69 \%(\$ 259 / \$ 376 \times 100)$ of the cost of targeted screening using risk criteria recommended in the Canadian Guidelines. However, using this strategy (age younger than 25 years or STD contact) would result in false economy. Four cases (28 versus 32 ) would be missed using with this strategy, and if these infections were transmitted to their sexual partners, the cost of caring for those infected partners would amount to $\$ 8,899.32$. The estimated direct cost of testing an additional 152 men $(384-232=152)$, at $\$ 31.31$ per test, to avert these four infections would only be $\$ 4,759.12$.

Given the enormous human and economic costs of genital chlamydial infection and adverse reproductive sequelae in women in Canada, and that screening and treatment of genital chlamydial infections have been shown to be effective in the prevention of pelvic inflammatory disease and the transmission of HIV, cost effective strategies to screen for asymptomatic infections in both men and women should be a priority $(36,37)$. Genç and Mardh (38) showed that the use of PCR for screening and azithromycin for treatment of asymptomatic chlamydial infection in women was cost effective if the prevalence of infection exceeded $6 \%$. In this study we showed that, at a prevalence of $7.8 \%$ in an STD clinic setting, targeted screening using urine PCR assays and risk assessment criteria recommended in the current Canadian STD Guidelines was as 
effective as universal screening but at substantially reduced costs. The estimated cost of this strategy also compares favourably with the estimated cost per case of chlamydial infection in men in Canada based on the less sensitive EIA which requires the use of urethral swab specimens. Further studies are needed to develop screening strategies in other settings and in populations with a lower prevalence of infection.

ACKNOWLEDGEMENTS: This work was supported in part by a grant from the Physicians Services Incorporated Foundation. The authors thank the physicians and staff at the Ottawa-Carleton Sexual Health Centre, and M Bobrowska-Gacek for excellent technical assistance.

\section{REFERENCES}

1. Canada Communicable Disease Report Supplement. Notifiable Diseases Annual Summary 1993. Health Canada 1995;21S1:ISSN 1188-4169.

2. Laga M, Manoka A, Kivuvu M, et al. Non-ulcerative sexually transmitted diseases as risk factors for HIV-transmission in women: results from a cohort study. AIDS 1993;7:95-102.

3. Centers for Disease Control and Prevention. Recommendations for the prevention and management of Chlamydia trachomatis infections. Morb Mortal Wkly Rep 1993;42(RR-12):1-39.

4. Washington AE, Johnson RE, Sanders LL. Chlamydia trachomatis infections in the United States: what are they costing us? JAMA 1987;257:2070-2.

5. Chlamydial infections in Canada. Can Dis Weekly Rep 1991; 17-51:282-291.

6. Bowie W. The sexually transmitted disease epidemic in Canadian adolescents. Can J Obstet Gynaecol 1993;5:399-402.

7. Goeree R, Gully P. Prevention of Infertility: The Burden of Chlamydial and Gonococcal Infection in Canada. Research Studies of the Royal Commission on New Reproductive Technologies, vol 8. Ottawa: Canada Communications Group, 1993:chapter 3, 29-76.

8. Peeling R. Chlamydia trachomatis and Neisseria gonorrhoeae: pathogens in retreat? Curr Opin Infect Dis 1995;8:26-34.

9. Lin JSL, Jones WE, Yan L, et al. Underdiagnosis of Chlamydia trachomatis infection: diagnostic limitations in patients with low-level infection. Sex Transm Dis 1992;19:259-65.

10. Talbot H, Romanowski B. Factors affecting urine EIA sensitivity in the detection of Chlamydia trachomatis in men. Geniturin Med 1994;70:101-4.

11. Peeling R, Brunham R. Molecular techniques for the laboratory identification of Chlamydia trachomatis. J Intern Fed Clin Chem 1994;6:78-82.

12. Toye B, Peeling R, Jessamine P, Claman P, Gemmill I. Diagnosis of Chlamydia trachomatis infections in asymptomatic men and women by PCR assay. J Clin Microbiol 1996;34:1396-400.

13. Quinn T, Welsh L, Lentz A, et al. Diagnosis by Amplicor PCR of Chlamydia trachomatis infection in urine samples from women and men attending sexually transmitted disease clinics. J Clin Microbiol 1996;34:1401-6.

14. Bauwens JE, Clark AM, Loeffelholz MJ, Herman SA, Stamm WE. Diagnosis of Chlamydia trachomatis urethritis in men by polymerase chain reaction assay of first-catch urine. J Clin Microbiol 1993;31:3013-6.

15. Jaschek G, Gaydos CA, Welsh L, Quinn TC. Direct detection of Chlamydia trachomatis in urine specimens from symptomatic and asymptomatic men by using a rapid polymerase chain reaction assay. J Clin Microbiol 1993;31:1209-12.

16. Pasternack R, Vuorinen P, Kuukankorpi A, Pitkajarvi T, Miettinen A. Detection of Chlamydia trachomatis infections in women by Amplicor PCR: Comparison of diagnostic performance with urine and cervical specimens. J Clin Microbiol 1996;34:995-8.

17. Chernesky M, Lee H, Schachter J, et al. Diagnosis of Chlamydia trachomatis urethral infection in symptomatic and asymptomatic men by testing first-void urine in a ligase chain reaction assay. J Infect Dis 1994;170:1308-11.

18. Chernesky M, Jang D, Lee H, et al. Diagnosis of Chlamydia trachomatis infections in men and women by testing first-void urine by ligase chain reaction. J Clin Microbiol 1994;32:2682-5.

19. Van Doornum G, Buimer M, Prins C, et al. Detection of Chlamydia trachomatis infections in urine samples from men and women by ligase chain reaction. J Clin Microbiol 1995;33:2042-7.

20. Buimer M, Van Doornum G, Ching S, et al. Detection of Chlamydia trachomatis and Neisseria gonorrhoeae by ligase chain reaction-based assays with clinical specimens from various sites: Implications for diagnostic testing and screening. J Clin Microbiol 1996;34:2395-400.

21. Deguchi T, Yasuda M, Uno M, et al. Comparison among performances of a ligase chain reaction-based assay and two enzyme immunoassays in detecting Chlamydia trachomatis in urine specimens from men with nongonococcal urethritis. J Clin Microbiol 1996;34:1708-10.

22. Pasternack R, Vuorinen P, Miettinen A. Evaluation of the Gen-Probe Chlamydia trachomatis transcription-mediated amplification assay with urine specimens from women. J Clin Microbiol 1997;35:676-8.

23. Chow JM, Moncada J, Brooks D, Bolan G, Shaw H, Schachter J. Is urine leukocyte esterase test a useful screening method to predict Chlamydia trachomatis infection in women? J Clin Microbiol 1996;34:534-6.

24. Änestad G, Berdal BP, Scheel O, et al. Screening urine samples by leukocyte esterase test and ligase chain reaction for chlamydial infections among asymptomatic men. J Clin Microbiol 1995;33:2483-4.

25. Patrick DM, Rekart ML, Knowles L. Unsatisfactory performance of the leukocyte esterase test of first void urine for rapid diagnosis of urethritis. Geniturin Med 1994;70:187-90.

26. Tyndall M, Nasio J, Maitha G, et al. Leukocyte esterase urine strips for the screening of men with urethritis - use in developing countries. Genitourin Med 1994;70:3-6.

27. Sellors J, Mahony J, Pickard L, et al. Screening urine with a leukocyte esterase strip and subsequent chlamydial testing of asymptomatic men attending primary care practitioners. Sex Transm Dis 1993;20:152-7.

28. Shafer M, Schachter J, Moncada J, et al. Evaluation of urine-based screening strategies to detect Chlamydia trachomatis among sexually active asymptomatic young males. JAMA 1993;270:2065-70.

29. Knud-Hansen CR, Dallabetta GA, Reichart C, Pabst KM, Hook EW III, Wasserheit JN. Surrogate methods to diagnose gonococcal and chlamydia cervicitis. Sex Transm Dis 1991;18:211-6.

30. Sanders JW, Hook EW III, Welsh LE, Shephard ME, Quinn TC. Evaluation of an enzyme immunoassay for detection of Chlamydia trachomatis in urine of asymptomatic men. J Clin Microbiol 1994;32:24-7.

31. 1995 Update Canadian STD Guidelines. Can Commun Dis Rep 1995; Supplement 21S4:158.

32. Hart G. Factors associated with genital chlamydial and gonococcal infection in males. Genitourin Med 1993;69:393-6.

33. Van Duynhoven YTHP, van de Laar MJW, Fennema JSA, van Doornum GJJ, van den Hoek JAR. Development and evaluation of screening strategies for Chlamydia trachomatis infections in an STD clinic. Genitourin Med 1995;71:375-81.

34. Genç M, Ruusuvaara L, Mardh P. An economic evaluation of screening for Chlamydia trachomatis in adolescent males. JAMA 1993;270:2057-64.

35. Janier M, Lassau F, Casin I, et al. Male urethritis with and without discharge: a clinical and microbiological study. Sex Transm Dis 1995;22:244-52.

36. Scholes D, Stergachis A, Heidrich F, Andrilla H, Holmes K, Stamm W. Prevention of pelvic inflammatory disease by screening for cervical chlamydial infection. $\mathrm{N}$ Engl J Med 1996;334:1362-6.

37. Grosskurth H, Mosha F, Todd J, et al. Impact of improved treatment of sexually transmitted diseases on HIV infection in rural Tanzania: randomised controlled trial. Lancet 1995;346:530-6

38. Genç M, Mardh P-A. A cost-effectiveness analysis of screening and treatment for Chlamydia trachomatis infection in asymptomatic women. Ann Intern Med 1996;124:1-7. 


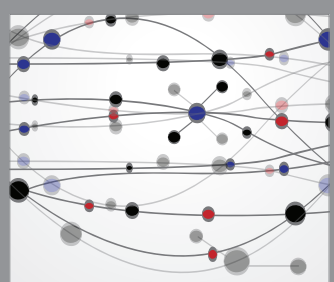

The Scientific World Journal
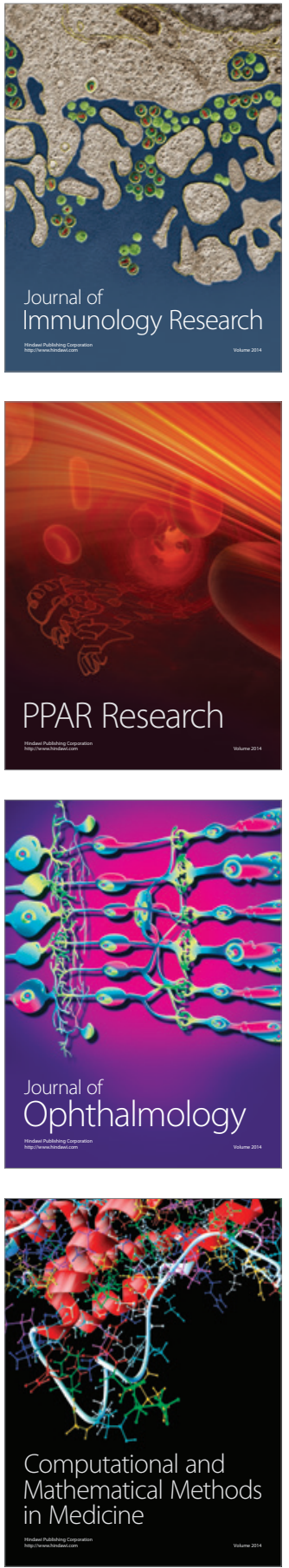

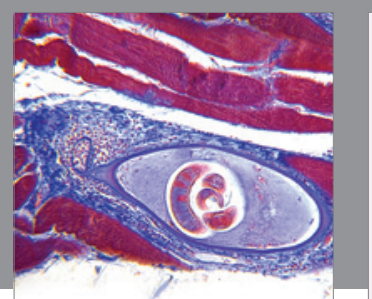

Gastroenterology Research and Practice

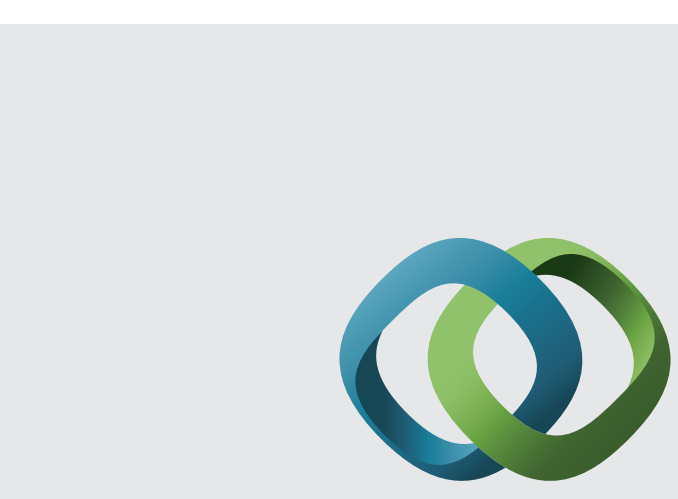

\section{Hindawi}

Submit your manuscripts at

http://www.hindawi.com
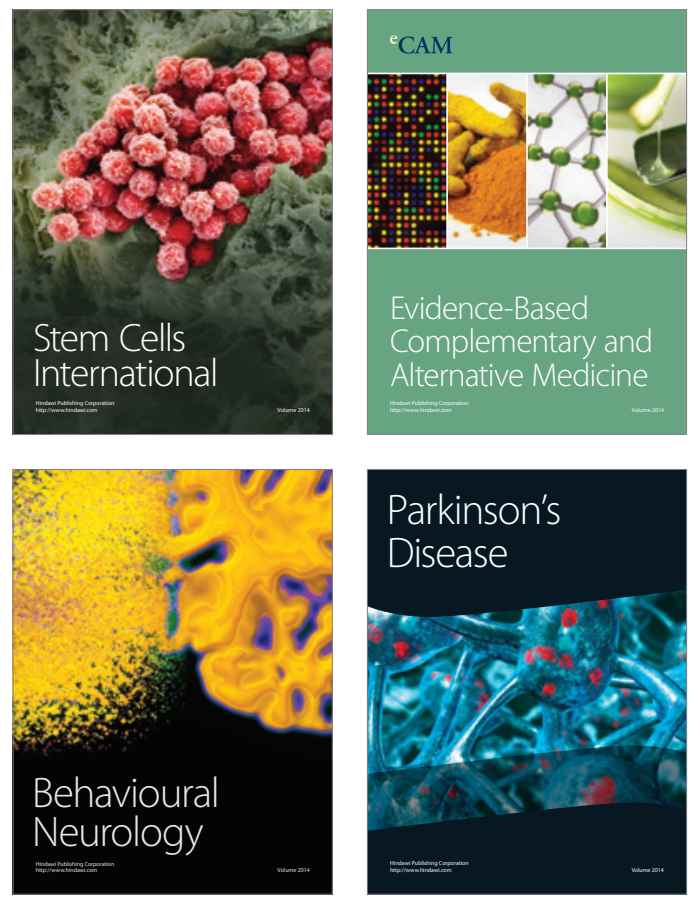
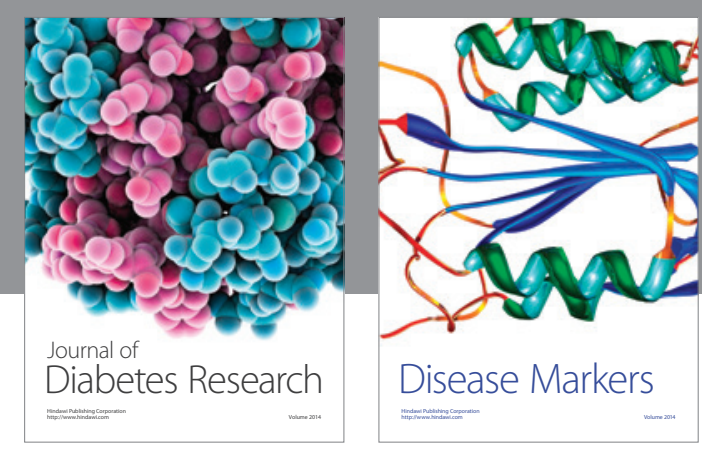

Disease Markers
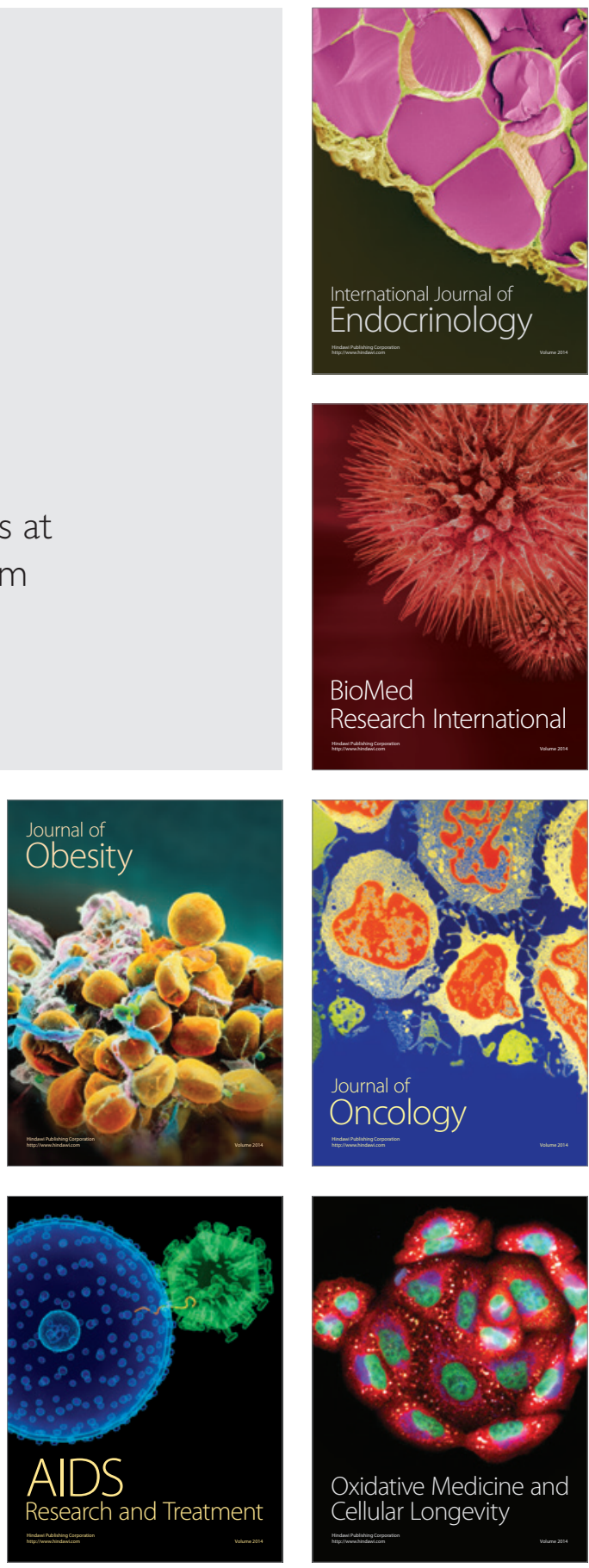